決定論的立場からの海峡部 tidal - exchange の観測とその制御策の検討

Field observation of tidal-exchange through straits from deterministic view points and consideration of methods to control the process

$\bigcirc$ 東京理科大学 正員 大 西 外 明

" " 西村司

1.は じめに

近年、各種の産業活動の規模は次第に大規模化し、それに伴ない、海、河川、湖沼などの水質劣化の問題 が重大な社会的関心事となりつつある。特に内海部に拈いては、内海と外洋との間の海水交換が、狭い海 峡によって妨げられるために、問題はより深刻であり、それに対し有効な対策を講じる必要に迫られている。

海峡をとおしての海水交換に関しては、従来より種々の研究がなされているが、それらの多くは、海峡を 通過する潮流を乱流構造として把えるあのである。しかしながら、海水交換を工学的に制御することによ り水域の水質改善を図るといった実際的視点からいえば、乱流構造の内部に立ち入った詳細な検討は必らず しも必要では無く、又有効でも無い。 又、海水交換という大スケールの現象を、乱流の持つ確率統計的な 性質に関連づけるための現地観測は一般に困難である。そこで本研究は、海峡部潮流現象を、海峡部中央 部水域のポテンシャル流領域と、海峡陸岸近傍水域の乱流境界層とに分け、更に、乱流境界層を、最近主と して実験室規模で研究されはじめた coherent 構造理論によって検討するという決定論的手法により取 り扱う立場をとる。その際、coherent 構造理論の展開において大きい役割を演ずる“流れの可現化 手法”としては、航空機あるいは Landsat からのリモートセンシングを導入する。 また、水理実験 を併用しながらリモートセンシングデータを水理学的に判読することによって、海峡をとおしての海水交換 の決定論的機構を明らかにし、土木構造物を用いた、乱流境界層制御による海水交換の工学的制御策につい て検討する。

\title{
2. 確率統計論的立場と決定論立場との比較検討
}

海峡部の海水交換の現状把握や予測あるいはその工学的制御策の検討にあたっては、単に海水交換の総量 を把握するのみならず、海水交換に関与する水理学的メカニズムを明らかにする必要がある。海峡の潮流 に関連したこのような海水交換現象を水理学的にとり扱う研究の立場としては、大きく分けて確率統計論的

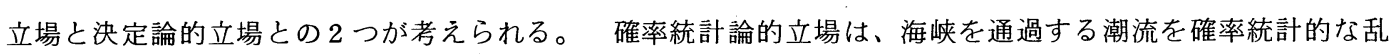
流構造として把握し、海峡をとおしての海水交換を乱流混合の1つの形態であると考え、乱れによって生じ る乱れ速度の 2 次モーメントによりこれを表現しようとするあのであり、非完結性を持つこの問題の解決方 法として Bradshaw らの準 2 次モデルや、SmagoriskyーDeadorff モデルなどがある。 一方 決定論的立場では、海水交換現象は海峡を通過する潮流の方向の反転前後の質量輸送が不等であることに原 因するあのと考えるあのである。 また、乱れ速度の 2 次モーメントを渦動粘性係数や混合距離を用いて表 現する方法は、乱れとは無関係な平均流速の勾配を用いる点において決定論的立場に立つあのと言えよう。 この方法を用いた海水交換に関する研究としては速水ら $5^{2}(1956)$ のあの゙ある。速水らは凍結乱流の仮定 および混合距離の概念を用いて明石海峡について考察し、同海峡における海水交換の総量を潮汐半周期あた

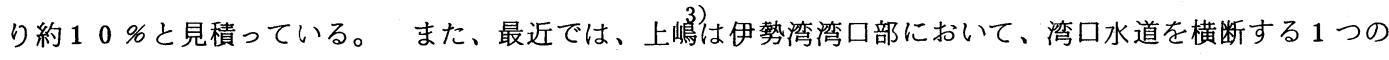
検査面上の多数の測定点における流速および塩素量の連続長時間測定記録を屯とに、海水交換の総量を決定 論的に把握するとともに、流速および塩素量の場所的、時間的変動の間の相関を検討し、それに基づいて海 水交換の総量を構成する種々のメカニズム各々に起因する海水交換項を確率統計論的立場から評価している。 海峡水域の潮流の乱流構造を相関の面的な分布として表現するために必要とされる諸量を、潮流が激しく、 又交通量の多い海峡水域に打いて現地観測によって求めることには多くの困難があり、レイノルズ応力を具 
体的に記述する問題は未解決のまま残されている。

確率統計論的立場からのアプローチは、乱流の持つ統計論的性質を数理的に表現し得る点においては決定 論的立場に対して優位にあり、乱流現象としての海水交換現象の流体力学的解明に寄与する所が大きい屯の と考えられるが、たとえば海水交換を工学的に制御することにより水域の水質改善を図るといった、現場に おける実際の局面に扔いては、乱流構造を厳密にbreak-down する事は、必ずし屯常に必要とはされず むしろ現地調査結果との関連付けの容易さや解析手法の簡明さがより重要視され、決定論的立場からのアプ ローチが重要視されることが多くなる。 また、潮汐による海水交換に関与する水域の広さは、現実には広 大であり、したがって対象水域を一望の下においてその現象を模型水槽内におけるが如く 1 時に観測するこ とが㛜密には必要であるが、この様な解析を行なう時、本来確率統計的性質を有する乱流構造は、場所的に 屯、時間的にあほぼ不変となり、現象を、海峡中央部水域のポテンシャル流れ領域と海峡近傍水域の境界層 とに分けて決定論的に見ることになる。

さらに又、乱流境界層内部の乱流構造をむ決定論的に取り扱おうとする試みが 1970 年代にはいってな され始めている。すなわち、winant $5^{4}$ ( $\begin{aligned} & 19 \\ & 9\end{aligned} 74$ ) は、実験によって、自由乱流境界層内の比較的規則 的な渦列構造 ( coherent 構造)を見出し、coherent 構造を構成する個々の渦 (coherent 渦) の運動、渦同士の合併などの、渦の決定論的挙動をむとに自由乱流境界層の構造を明らかにしてゆく方法を 提案した。しかし、従来の coherent 構造研究は主として実験室スケールの乱流境界層(レイノルズ数 が $10^{5}$ のオーダー) を対象として進められてきており、それよりスケールのはるかに大きい海峡部潮流の 乱流境界層（レイノルズ数が 100 のオーダー）の把握への適用例は見当らない。これは、coherent 構造研究に拀いて 1 つの重要な研究手段である流れの可視化手法を、従来の技術ではこの様な大スケールの 乱流構造へ適用することが困難であったことによる。

以上の様に、海峡をとおしての潮流による海水交換という大スケールの乱流現象を可視化した上で観測す ることが可能であれば、海峡中央部のポテンシャル流部およびその両側の乱流境界層部の双方を併せて決定 論的に取り扱えることになる。そこで本論文においては、この様な大スケールの流れの可視化法として航 空機および人工衛星によるリモートセンシングを導入して、海峡における潮流および海水交換現象を決定論 的に把握し、その結果を水理実験により検証することによってその手法の有効性を示す。なお、対象水域 としては、瀬戸内海と外海とを結ぶ5つの海峡のうち、鳴門海峡、友ケ島水道、明石海峡の 3 つの海峡をえ らんだ。

写真- 1 鳴門海峡における自由乱流境界層と coherent 構造（(a)6.6/ット(b)9.1/ット）

(a)

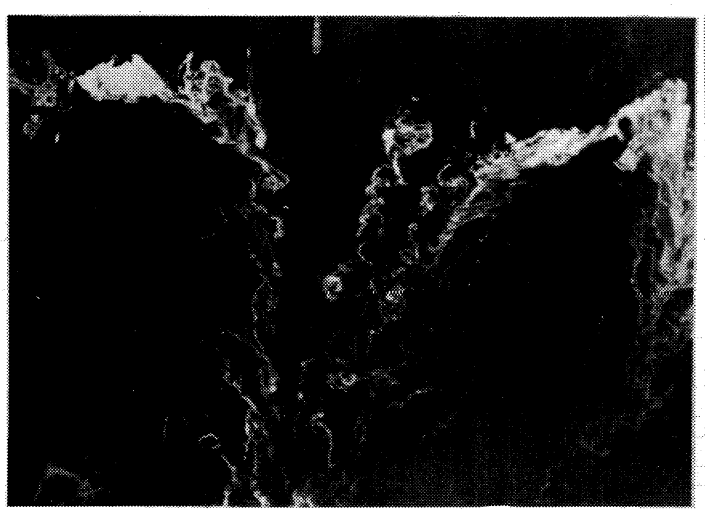

(b)

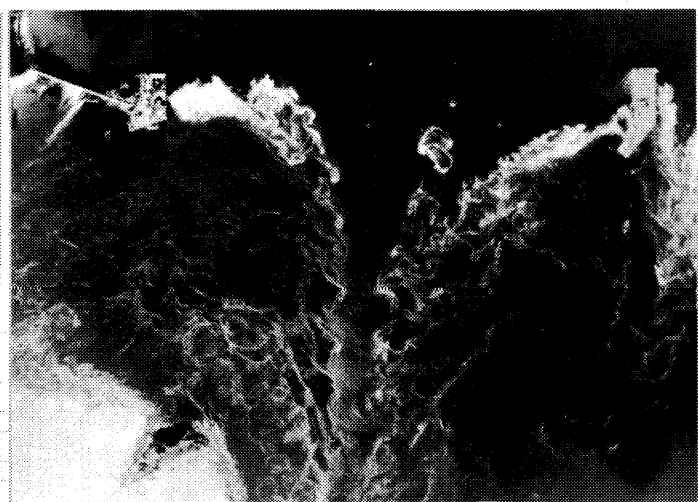


3.リリートセンシングを用いた現地観測

(1) 海峡近傍水域の乱流現象の決定論的描像

写真一（a)、（b）は鳴門海峡の上空 $800 \mathrm{~m}$ から得られた航空写真であって海峡中央部の潮流流速は、 (a) が 6.6 ノット（b）が 9.1 ノットの状態の下での潮流状況であり、自由乱流境界層の位置形状、境界層内部 の coherent 構造の配置そのものも観測時間および潮流流速を異にする 2 つの場合に同じとなっている。 このことは、海峡を通過する潮流を大まかには、自由乱流境界層を自由流線と理想化したポテンシャル流れ として決定論的に解析することが可能であるという事を示唆しているあのと考えられる。又、自由乱流境 界層中のいわゆる “鳴門の渦”は、両側の陸岸突出部先端に扔いて剥離した渦度の集積した coherent 渦 であると考えられる。

(2) 半潮流サイクルの大スケール渦の形成

海峡を通過する潮流は 1 サイクルが約 12 時間弱の往復流であるから、最初の半潮流サイクル 6 時間にわ

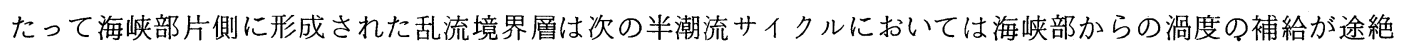
え、海峡を挟んで反対側の水域に新たに乱流境界層が形成される。 coherent 構造理論によれば、壁面 乱流境界層よりあ自由乱流境界層に扔いての方が coherent 渦への渦度の集積および coherent 渦同士 の合併の過程が効率良く行なわれる( Davies $5^{5)}$ )。従って、自由乱流境界層を形成し易い様な海峡 地形、即ち境界層の剥離を生じ易い地形形状を有する海峡においては、剥離した渦度の集積した coherent 渦が更に半潮流サイクル約 6 時間にわたって合併を重ね大スケールの渦を形成するすのと考えられる。

そこで本論文においては、地形特性のそれぞれ異なる鳴門海峡、友ケ島水道拉よび明石海峡について、この 大スケール渦の形成過程执よびその結果生じる大スケール渦の挙動を検討し、図ー1 (a)、(b)、(c) に模式 的に示す結果を得た。前 2 者は筆者らの行なった Landsat 映像解析によって得られたあのであり、明 石海峡については藤原のデータを参考にした。なお、これらのデータはすべて、大潮時を対象としたもの である。

図ー 1 海峡における潮流によって形成される大スケール渦の挙動

\section{Large-scale vortex formation}

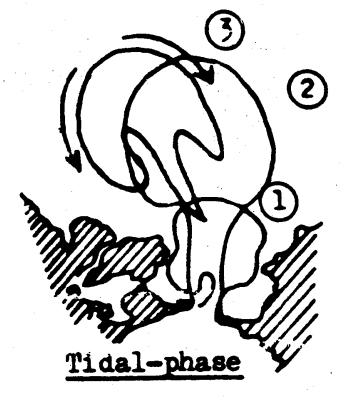

(2)

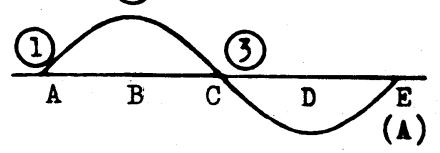

（a）鳴 門 海 峡
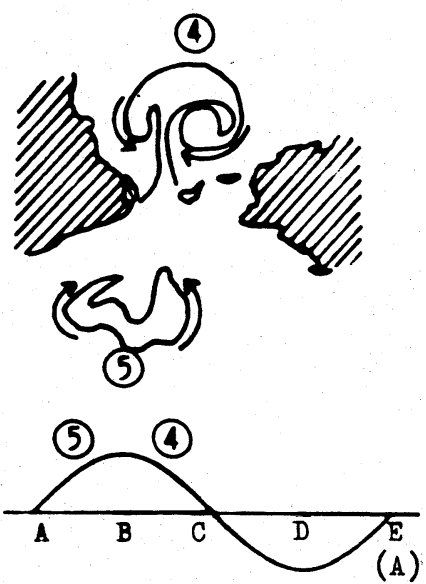

（b）友ケ島水道
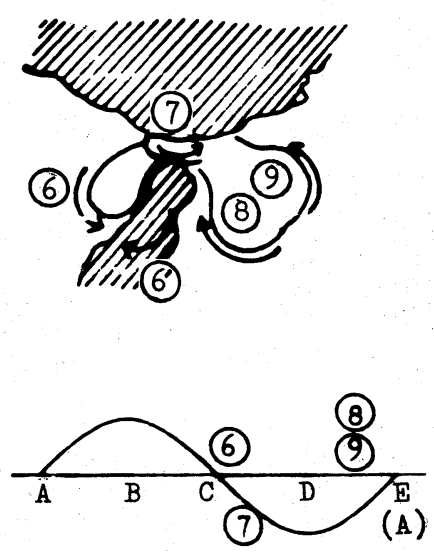

（c）明 石 海, 峡 
4. 海水交換の水理学的機構

リモートセンシングデータの得られた 3 つの海峡の各々について、大スケールの渦の形成、発達および運 動の過程を検討し、それを基にして決定論的な海峡部海水交換の水理学的機構につき考察し、縮尺地形模型 実験によってその検証を行なう。

(1) 鳴 門 海 峡

図一1（a）において、(1) は北流最強時における大スケール渦形成の途中（2) は形成し終えた状態 (3) は 形成された大スケール渦が渦対をなして海峡に向かう南向き潮流の中を渦対固有の自己誘導速度 $\mathrm{U}_{\mathrm{V}}$ の速度

$$
\mathrm{U}_{\mathrm{V}}=\frac{\Gamma}{2 \pi \ell}
$$

で北上している状況を示す。ここに $\Gamma$ は大スケール渦の強さ $\ell$ は 2 つ渦の間隔である。 今、 $\mathrm{U}_{\mathrm{v}}$ が充分に大きく、渦対が次の南向き半潮流サイクル約 6 時間の間に再び海峡部に流入しないならば海水交換 は極めて効率良く行なわれる。

鳴門海峡における渦対の 1 潮流サイクル約 12 時間にわたる挙動を把握するために、往復潮汐流水槽に設 置した現地海峡地形の縮尺模型を用いて水理実験を行なった。水平縮尺 $1 / 20,000$ 鉛直縮尺 $1 / 1,667$ の歪み模型を用い、フルード相似により水理量を設定した。なお、視点を渦度の大スケール渦への集積過 程に置いているために、その過程に大きい影響を与える底面粗度は入れていない。代表長さとして海峡幅 代表流速として最強時海峡部潮流流速を用いた場合のレイノルズ数は、現地で約 $10^{9)}$ 模型で約 $10^{4)}$ であ る。写真一 2 (a) は北流により形成される大スケール渦の挙動を念頭に置き、最強流時 10 ノットの潮

写真一 2 鳴門海峡における大スケール渦の挙動と海水交換（模型実験： 10 ノット）

(a)

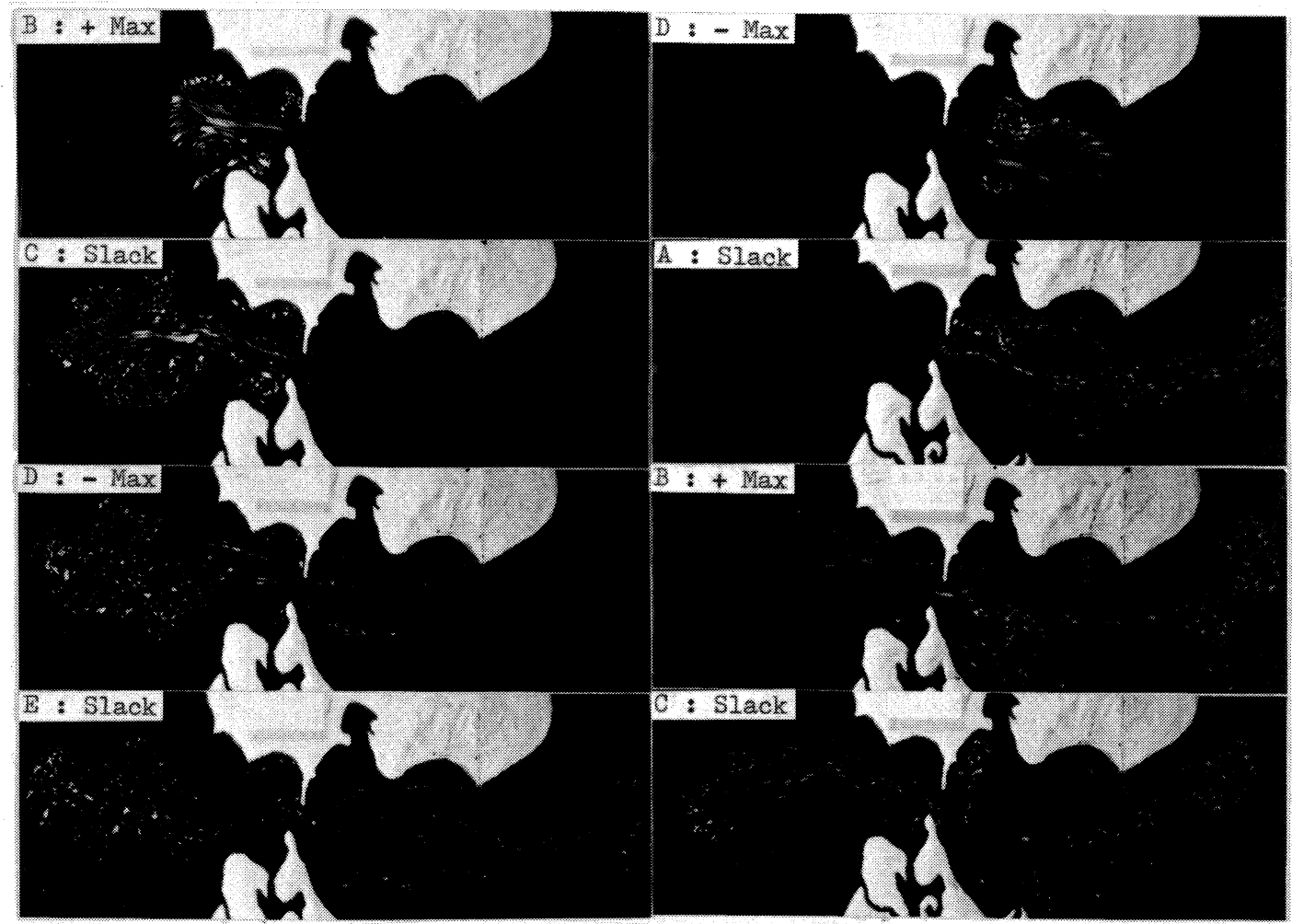


流を与えた場合の 1 潮流サイクルの 3 時間ごとの各位相における大スケール渦の様子を示したものである。 大スケール渦からなる渦対 B、C、D は、現地の Landsat リモートセンシングによって得られた渦 対 (1)、(2)、(3) と殆んど一致した挙動を示し、この様な大縮尺の歪み模型に扔いても大スケール渦の挙動 の相似性が保証されるという興味ある結果が得られる。 又、模型においても、染料による可視化によって 自由乱流境界層内の c o h e r e n t 渦同士の合併の過程を明膫に観察することができる。

鳴門海峡をとおしての南向きの海水交換を支配するところの、海峡南側水域に形成される大スケール渦の 挙動については、現時点ではそのリモートセンシング情報は得られていない。そこで、水理模型実験によ って評価することとした。写真一2（b） は南流によって形成される大スケール渦の挙動追跡を目的とし て最強流時 10 ノットの潮流を与えた場合の、潮流華クルの 3 時間毎の各位相における大スケール渦の様 子を示したあのである。南流の場合は、北流の場合に較べて明瞭な渦対が形成されにくく、むしろ噴流の 形態をとり、渦対自身の誘導速度の効果が少ないために、海水交換能力が小さくなっている。海峡を挟ん での南北各々の水域の間のこの様な大スケール渦の形態の相違には、各々の間の海底地形との関連が深い屯 のと判断されている。

(2) 友ケ島水道

図-1（b）において、(4)は北流へ転流後約 2 時間 50 分後の大スケール渦形成終了前の状態、(5)南流 によって形成された大スケール渦が北流へ転流後 1 時間の時点においてもなお紀伊水道に存在している事を 示す。鳴門海峡と同様、と屯に左旋・右旋の渦からなる渦対を形成している。写真-3 (a)、 (b) は最 強流時 4 ノットの潮汐流を水平縮尺 $1 / 45,000$ 鉛直縮尺 $1 / 1,667$ の歪み模型上に与えた場合の、各 々、北流、南流によって形成される大スケール渦の 3 時間毎の各位相に打ける状況を示したあのである。 南流時においては、北流時に較べて形成される大スケール渦対の自己誘導速度の効果がより大きく、従って 海水交換の効率屯又良い。

写真一 3 友ケ島水道における大スケール渦の挙動と海水交換（模型実験 4 ノット）

(a)

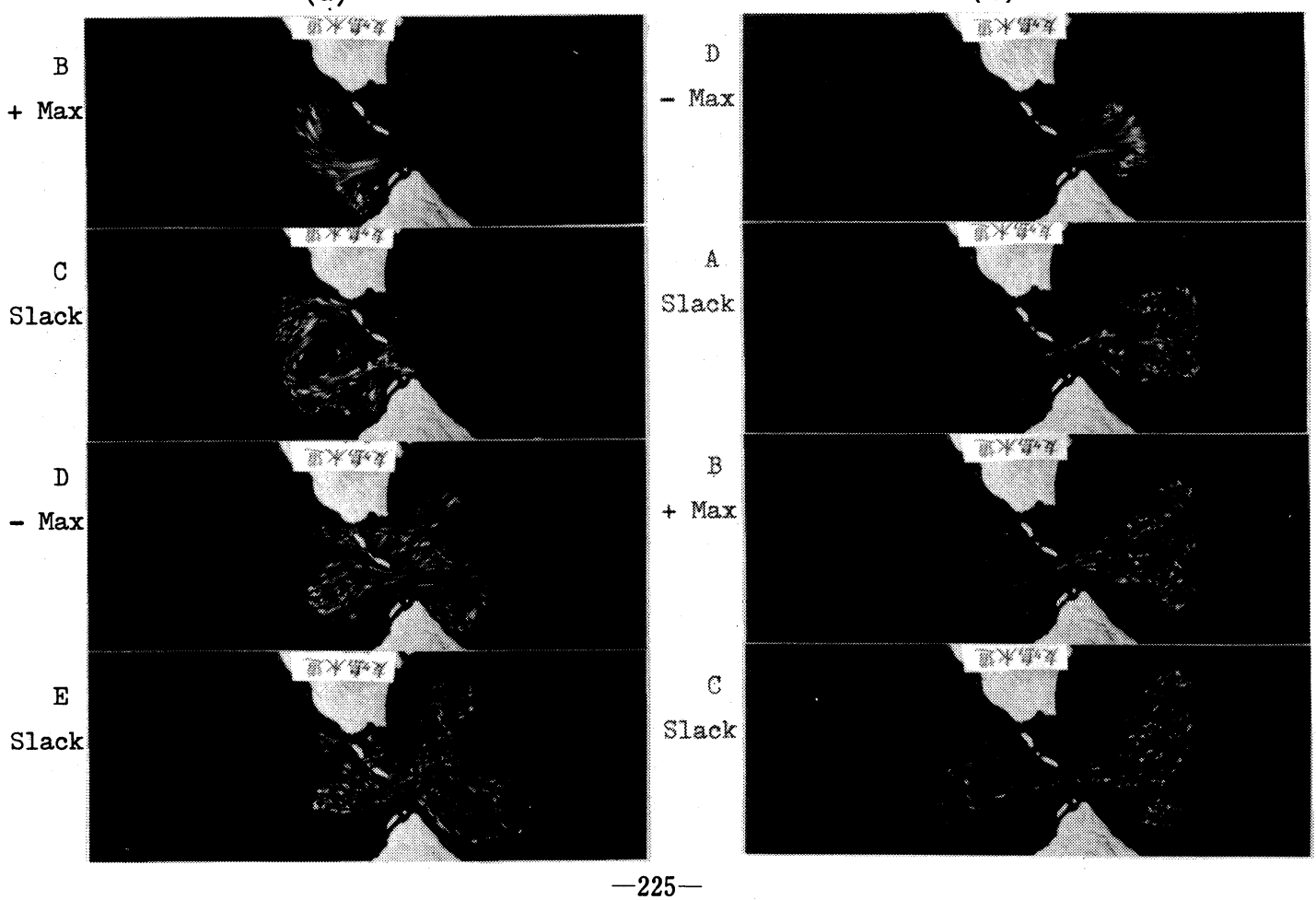


(3) 明 石 海 峡

図ー1（c）において、(6)は西流終了時に形成された大スケール渦である。明石側において、西流の場合、 地形がなだらかな形状をなすために境界層が剥離せず、壁面乱流境界層のままである。従って、coherent 淌の形成およびその合併の過程が効率良く行なわれず、大スケール洬は形成されない。この為に、淡路側 に形成された大スケール渦 (6) は渦対を形成することができず、むしろ、淡路島西側を挟んでの自分自身の 鏡像 (6) との間の誘導速度の効果によって海峡近傍水域を離れることを拒む挙動を示す。（7) は東流開始 直後の状況であり、大スケール渦（6)が海峡部に吸い込まれている状況を示している。（8)、（9）は東流 時の淡路島側に大スケール渦（8) が生じると共に明石側において屯大スケール渦 (9) が生じ、渦対をなして 大阪湾沖合に進行する様子を示している。藤原 ${ }^{7)}$ によれば、大スケール渦 (8) は次の西流半潮流サイクル を通じて大阪湾にとどまり続ける。写真一 4 (a)、（b)は最強流時 6.8 ノットの潮汐流を水平縮尺

$1 / 25,800$ 鉛直縮尺 $1 / 1,667$ の明石海峡地形模型上に与えた場合の、各々、西流、東流によって形成され る大スケール渦の 3 時間毎の各位相における状況を示したあのである。これらの検討結果より、明石海峡 は、西流によって大阪湾の海水を明石・淡路両岸沿いに吸い込み、次の東流によって大阪湾中央部に吹き出 すという㗢きをなしており、従って、海峡をとおしての実質の海水交換はそれ程大きくはない屯のと考えら れる。

写真 -4 明石海峡における大スケール渦の挙動と海水交換（模型実験：6.8ノット）

(a)

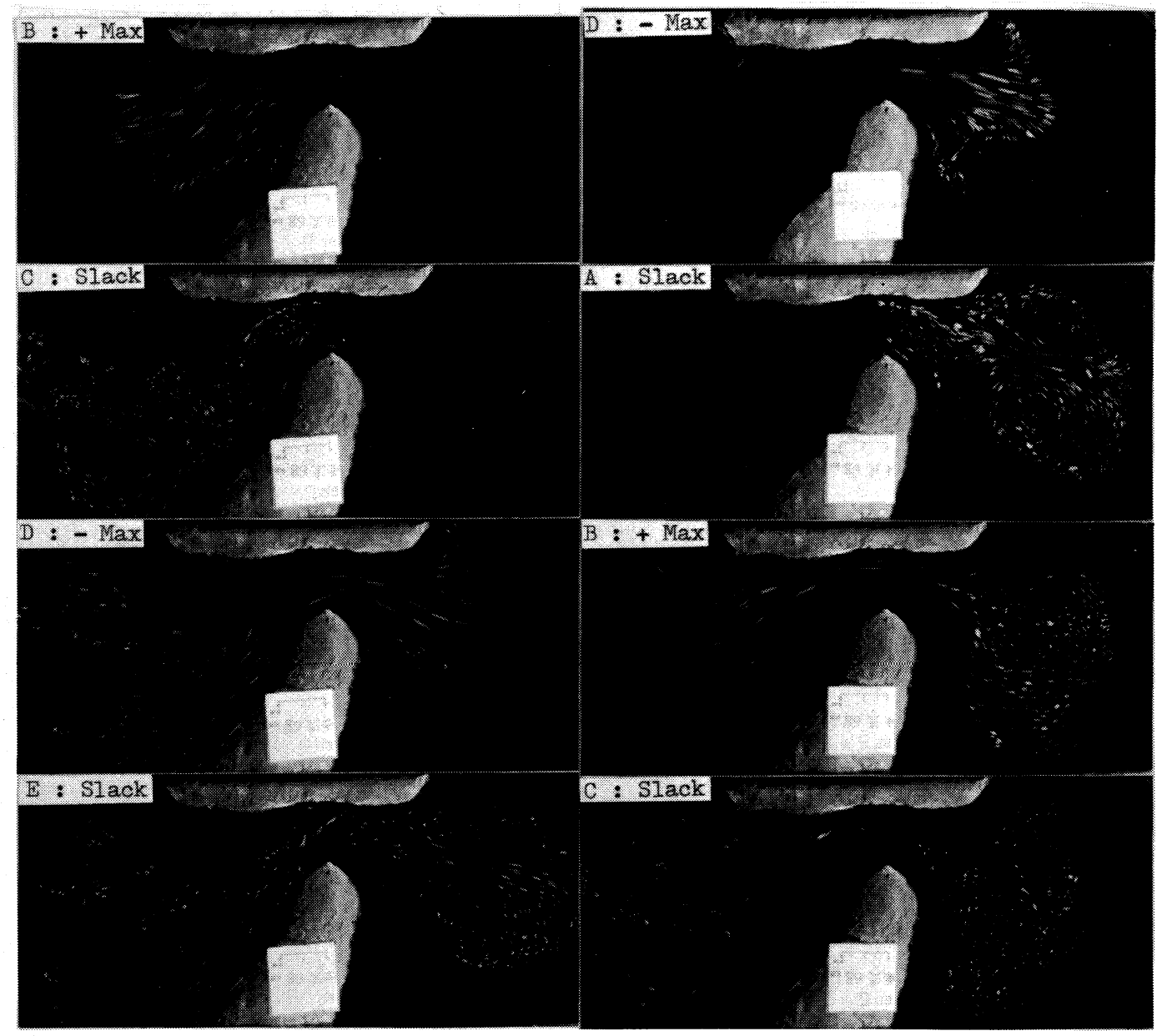




\section{5. 海水交換の工学的制御策の検討}

海峡部に設置した土木構造物によって海水交換を制御し内海水質の改善を図る可能性の検討を行なう。海 水交換の水理学的機構の考察から、海水交換が効率良く行なわれるには（i）海峡部において双方の陸岸から 渦度が剥離し自由乱流境界層を形成すること。（ii）各々の自由乱流境界層の内部の渦度がcoherent 渦の 段階を経て大スケールの渦へと効率良く集皘すること。(iii) 生じた 2 個の大スケール渦相互の、海峡から離 れる方向の誘導力が陸岸地形による海峡部にとどまる方向の誘導力よりあ大きいこと。の 3 者が必要であ ることが推測される。従って、海水交換の制御を行なうには、この 3 つの過程の制御策、すなわち境界層 制御策を講ずれば良い。ここでは、海峡近傍水域に突堤を設置することによって海水交換を促進する案を、 簡単化した模型を用いる水理実験によって検討する。

写真一 5 は海底地形の凹凸を考慮に入れない 2 次元的な海峡地形を用い、1 潮流サイクルにわたって大ス ケール消の挙動を追跡した模型実験結果の 1 例を示す。海峡幅 $10 \mathrm{~cm}$ 水深 $1.6 \mathrm{~cm}$ 最強流時のフルード数は 0.125 である。因みに明石海峡においては大潮時に約 0.15 である。突堤は $0.4 \mathrm{~cm} \times 0.1 \mathrm{~cm}$ の長方形 の屯のを写真中矢印の位置に設置した。各実験ケースにおける突堤設置の条件、大スケール渦形成状況お よび海水交換の効率は以下のとおりである。

（a）突堤なし：双方の陸岸から目由乱流境界層が発達し大スケール渦が形成されるが、陸岸の効果が渦 対の誘導速度の効果より大きい為に海水交換は効率良く行なわれない。

（b）一方の陸岸突端に突堤を設置：大スケール渦からなる淌対が生じ、淌対の誘導速度の効果が陸岸 の効果に滕り、海水交換率は改善される。突堤の設置によって壁面乱流境界層の剥離位置が固定され たために、突堤設 置側の渦が強くなり、従って渦対の進行方向は曲がる。

（c）双方の陸岸突端に突堤を設置 ：大スケール渦対が噴流の形態をとる。交換率は大きい。

（d）双方の陸岸流入部に突堤を 2 個づつ設置 ：大スケール渦対が効率よく形成され、交換率は大きい。 以上のことから、突堤の設置によって壁面乱流境界層の剥離を促すことにより、大スヶール渦からなる渦 対の形成を促進して海水交換促進を図るにあたっての1つの手掛りが得られたあのと考えられる。

6. 結語

以上、リモートセンシングの導入による現地䍹測および海峡陸岸沿いの境界層内部の coherent 渦の 集皘して生じる大スケール渦に着目した水理実験の 2 つの手段を用いて決定論的立場から海水交換を論じた。 その結果、大スケール渦の運動が狭い海峡をとおしての海水交換に大きい役割を果たしていることが明らか にされ、更に、海水交換の制御策の検討に対しての 1 つの手掛りが得られた。この様な決定論的アプロー チは、現時点では未だ定性的議論の段階であるという限界をわきまえておく限り、海峡部海水交換現象ある いは海峡水理現象の研究に対して極有効な手法であると考えられる。

謝辞 ：実験装置の製作、模型作成、実験に際し東京理科大学学生 柴吉寛、馬場康之、大北隆之、 橋本彰文の四氏の尽力を願った。深甚の謝意を表する。なお、本研究は昭和 54 年度文部省 科研費 (研究代表者 丸安隆和 東京理科大学教授)を受けた。

(参 考 文 献)

(1) 日野・大西・羽生：Deadorffモデルによる数値シミュレーション：第 18 回水講 p1-5（1974）

(2) 速水・福尾・依田 : 明石海峡による播磿灘と大阪湾の海水交換について：第 3 回海講 $\mathrm{p} \mathrm{49-53(1956)}$

(3) 上嶋：海峡部における物質輸送について：海洋学会秋季大会 p 8-9(1979)

(4) Winant - Browand : Vortex pairing : J.F.M.63 part2 p237-255(1973)

(5) Davies - Yule : Cherent structnres in turbulence : J.F.M. 69 part 3 p $513-537(1975$ )

(6) 大西・西村： Landsat リモートセンシングを導入した海峡部海水交換現象の研究：土木学会論文 
報告集投稿中

（7）藤原 ：海水交換（I）大阪湾にトラップされた播磿灘系水：海洋学会秋季大会 p1 2-13（1979）

写真 -5 突堤による大スケール渦の制御（模型実験・矢印に突堤を設置）

(a)

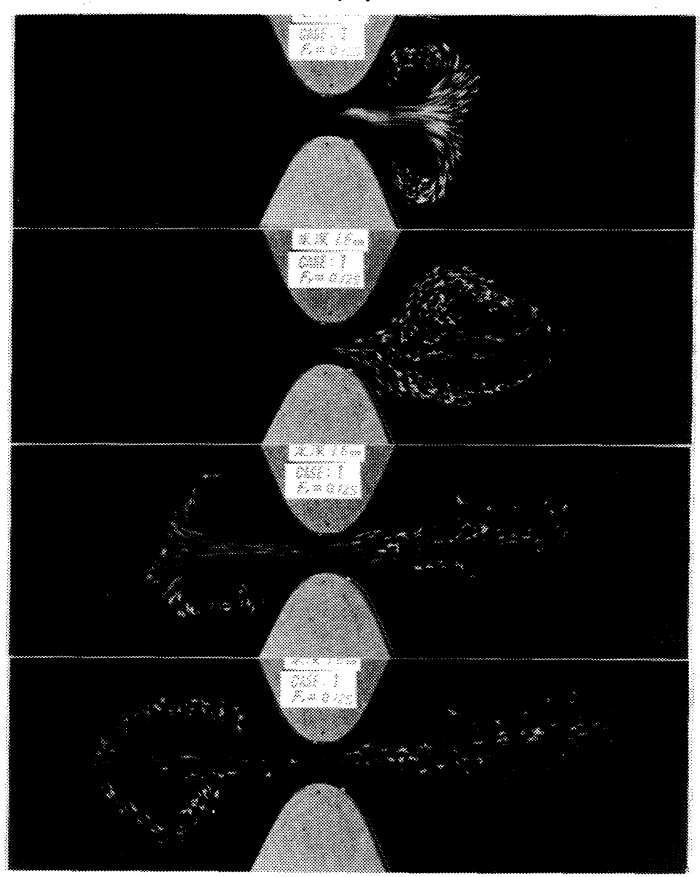

(c)

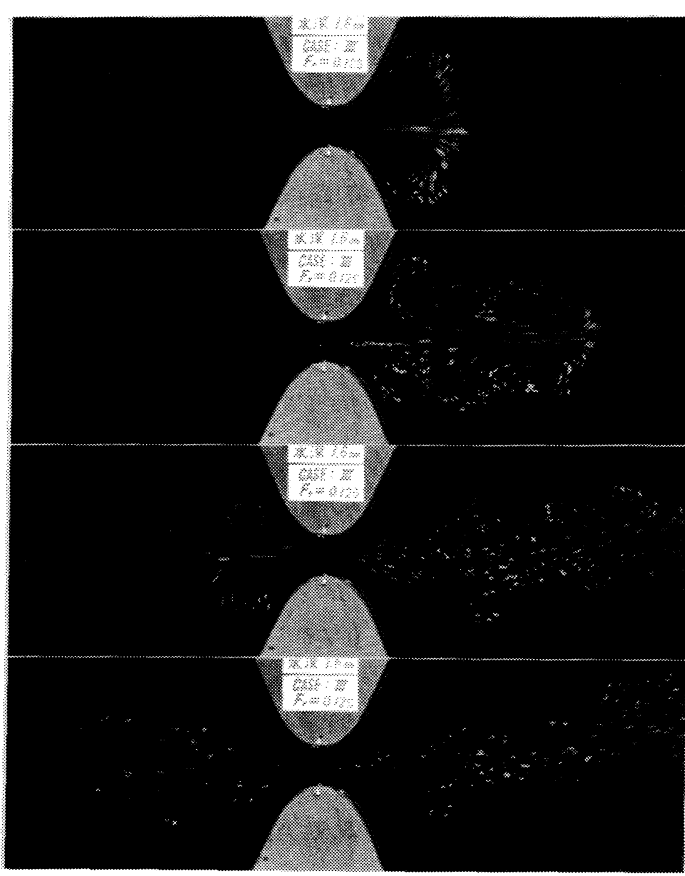

(b)

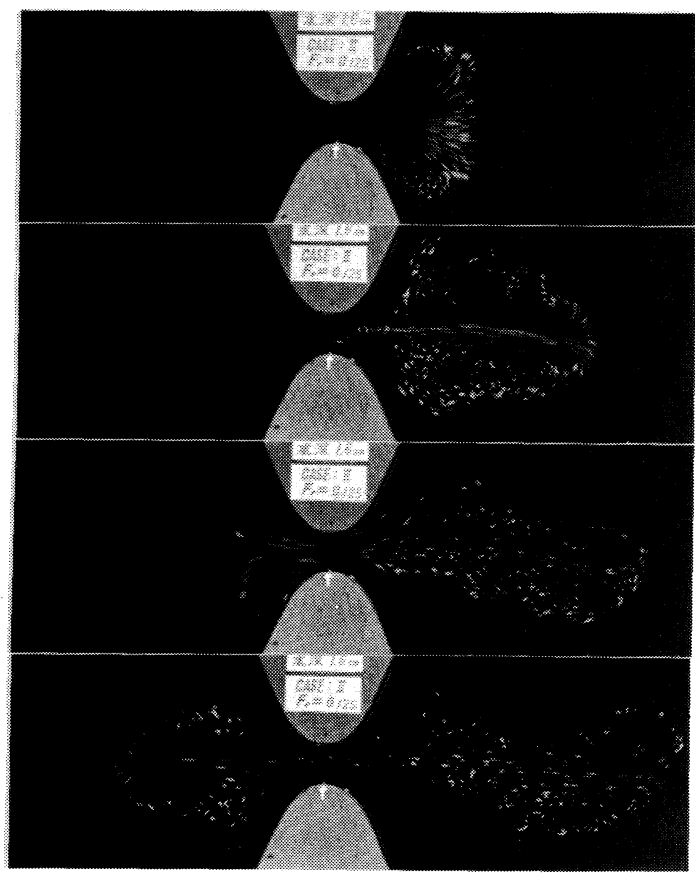

(d)

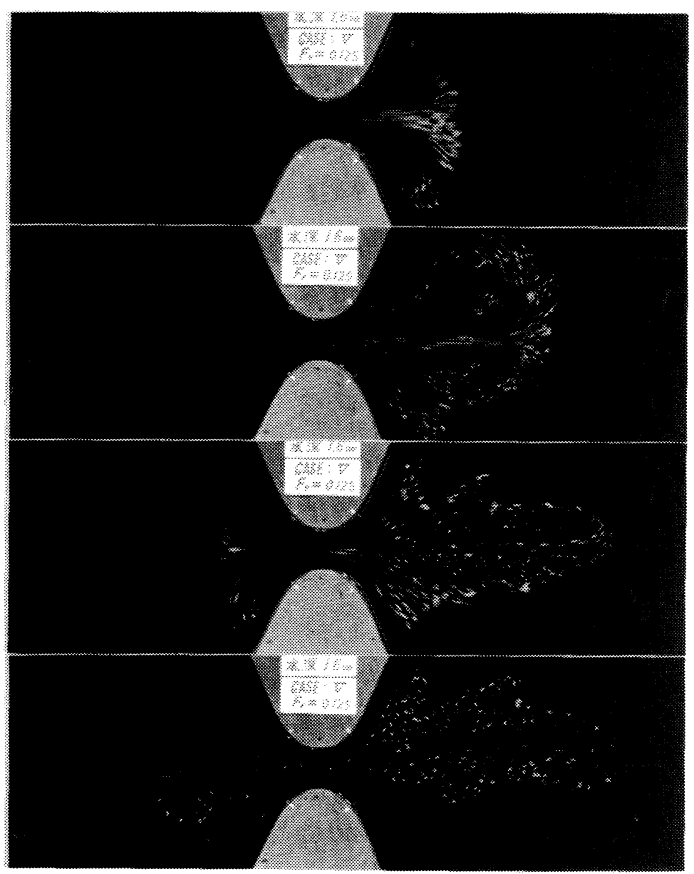

